\title{
MEMBANGUN BUDAYA LITERASI DI SEKOLAH
}

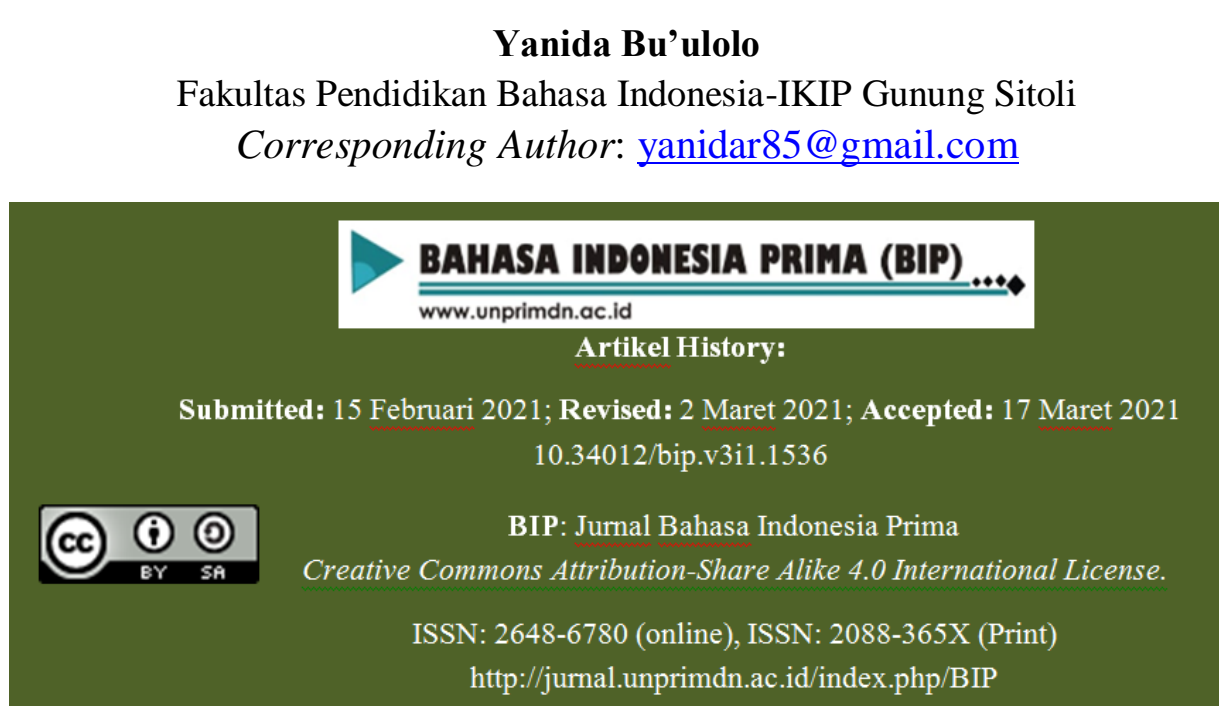

\begin{abstract}
Abstrak-Kemampuan literasi pada awalnya diartikan sebagai keterampilan membaca dan menulis, tetapi pada saat ini pengertiannya mengalami perkembangan. Khusus untuk mata pelajaran bahasa Indonesia pengertian literasi lebih dipumpunkan pada keterampilan informasi. Kemampuan informasi mengacu pada beberapa aktivitas, yaitu mengumpulkan informasi, mengolah informasi, dan mengomunikasikan informasi. Ketiga aktivitas tersebut tidak dapat dilepaskan dari keterampilan membaca dan menulis, yang dilaksanakan guru dan siswa dalam proses pembelajaran di kelas. Aktivitas semacam ini sesuai dengan tuntutan proses pembelajaran menurut Kurikulum 2013 yang dikenal dengan istilah pendekatan saintifik. Berkaitan dengan pelaksanaan pembelajaran literasi maka guru harus memperhatikan empat aspek, yaitu sumber belajar, bahan ajar, strategi pembelajaran, dan penilaian.
\end{abstract}

Kata kunci : Membangun, Minat, Budaya Literasi.

\section{A. PENDAhuluan}

Dalam ranah pembelajaran, kemampuan literasi merupakan kemampuan penting yang harus dimiliki oleh setiap siswa untuk menguasai berbagai mata pelajaran. Sejalan dengan penjelasan dalam kurikulum saat ini bahwa bahasa adalah penghela ilmu pengetahuan maka bahasa Indonesia merupakan sarana penyampai ilmu pengetahuan. Dengan kata lain, keterampilan berbahasa anak terutama membaca dan menulis yang diperoleh melalui pelajaran bahasa Indonesia, sangat menentukan keberhasilan mereka dalam menguasai berbagai mata pelajaran lain.

Literacy erat kaitannya dengan istilah kemahirwacanaan. Sebagaimana telah dikemukakan pada baian awal, literasi secara luas dimaknai sebagai kemampuan berbahasa yang mencakup kemampuan menyimak, berbicara, membaca, dan menulis, serta kemampuan berpikir yang menjadi elemen di dalamnya. Tompkins (1991:18) mengemukakan bahwa literacy merupakan kemampuan menggunakan membaca dan menulis dalam melaksanakan tugas-tugas yang bertalian dengan dunia kerja dan kehidupan di luar sekolah. Sementara itu, Wells mengemukakan bahwa literacy merupakan kemampuan bergaul dengan wacana sebagai representasi pengalaman, pikiran, perasaan, dan gagasan secara tepat sesuai dengan tujuan.

Sulzby (1986) mengartikan literasi sebagai kemampuan membaca dan menulis. Dalam pengertian luas, literasi meliputi kemampuan berbahasa (menyimak, berbicara, membaca, dan menulis) dan berpikir yang menjadi elemen di dalamnya. Menurut Unesco, seseorang disebut literate apabila ia memiliki pengetahuan yang 
hakiki untuk digunakan dalam setiap aktivitas yang menuntut fungsi literasi secara efektif dalam masyarakat, dan pengetahuan yang dicapainya dengan membaca, menulis, dan arithmetic memungkinkan untk dimanfaatkan bagi dirinya sendiri dan perkembangan masyarakat. Sementara itu, Wells mengemukakan bahwa untuk menjadi literate yang sesunguhnya, seseorang harus memiliki kemampuan menggunakan berbagai tipe teks secara tepat dan kemampuan memberdayakan pikiran, perasaan, dan tindakan dalam konteks aktivitas sosial dengan maksud tertentu. Dalam hal ini literat diartikan sebagai mahir wacana (dalam Muhana, 2003; 20). Dengan demikian, dalam pembelajaran di kelas guru hendaknya melahirkan siswa yang literat.

\section{Jenis-jenis Literasi}

Ketiga jenis literasi ini mengarah pada aktivitas seni berbahasa yang diakui dalam berbagai kultur budaya yang berbeda.

\section{Literasi Visual}

Literasi visual merupakan kemampuan dimana individu memiliki kemampuan mengenali penggunaan garis, bentuk, dan warna sehingga dapat menginterpretasikan tindakan, mengenali objek, dan memahami pesan lambang (Read dan Smith, 1982). Secara umum, literasi visual berfokus pada penafsiran gambaran visual seseorang yang juga terkait dengan kemampuan membaca dan kemampuan menulis. Literasi visual memungkinakan anak yang baru masuk bangku sekolah untuk dapat menyusun gambaran visual sebuah cerita secara urut dan benar meskipun dia belum bisa membaca. Melalui literasi visual bahkan seorang anak kecil yang belum belajar berjalan akan dapat menyusun buku-buku pavorit ataupun bermacam alat bermainnya yang diserakkan orang dewasa yang ada di sekitarnya. Namun, tentu saja kemampuan literasi visual dikembangkan jauh di luar kemampuan awal di atas.

Dalam implementasinya, literasi visual dapat dilakukan melalui beberapa aktivitas dengan menggunakan beragam jenis media. Dua jenis media untuk mengembangkan literasi visual antara lain gambar dan film. Gambar- gambar yang diperuntukkan bagi kelas awal harus bervariasi mencakup foto, buku bergambar, hasil pekerjaan seniman terkenal, poster perjalanan, Buku-buku bergambar, gambar tentang aneka jenis makanan, dan bunga-bunga dan lain-lain. gambar harus menumbuhkan minat ank-anak hindari gambar yang tidak menambah pengetahuan anak, yang akan mengarahkan mereka untuk tidak berhenti memperhatian gambar dengan mengatakan "lihat itu!" atau "apakah itu?" (Hymes 1981). Pada dasarnya guru dapat memanfaatkan beragam jenis gambar yang ada di lingkungan sekitar anak, yang sesuai untuk pencpaian tujuan pembelajaran.

Media lain yang dapat meragsang literasi visual anak adalah film. Gerakan gambar dalam film dapat mengarahkan kemampuan literasi anak. film haruslah dipilih sesuai minat anak yakni, film yang bercerita tentang kehidupan dunia anak yang realistik, sepert film boneka Si Unyil dan film-film cerita animasi yang sangat bagus untuk diperlihatkan kepada siswa misalnya cerita Petualangan Dora. Dalam implementasinya, gambar dan film-film yang sarat dengan bahan tersebut dibahas guru bersama siswanya.

\section{Literasi Lisan}

Seseorang yang menganut perspektif orasi mengaggap bahwa kebutuhan yang paling utama dalam berkomunikasi adalah berbicara dan mendengarkan. Sementara itu, membacamenulis dipandang sebagai keterampilan penting, tetapi bukan sebagai keterampilan primer yang dibutuhkan dalam kehidupan sehari-hari. Namun, para penganut perespektif literasi berpendapat sebaliknya. Mereka menganggap bahwa keterampilan membaca dan menulis merupakan keterampilan yang utama.

\section{Literasi Terhadap Teks Tertulis (Cetakan)}

Literasi terhadap teks tertulis atau tercetak digambarkan sebagai aktivitas dan keterampilan yang berhubungan secara langsung dengan teks yang tercetak, baik melalui bentuk pembacaan maupun penulisan. Di negara-negara maju, seseorang yang memiliki kemampuan membaca dan menulis pada tingkatan tertentu dianggap sebagai masyarakat modern. Mereka 
mengaggap bahwa penggunaan media cetak atau tulisan merupakan aktivitas yang utama dalam kebidupan keseharian mereka.

\section{B. PEMBAHASAN}

\section{Membangun Budaya Literasi}

Dari kenyataan yang kita saksikan tentang pembelajaran bahasa Indonesia di atas, maka arah pembelajaran harus diubah. Pembelajaran bahasa Indonesia yang diarahkan pada upaya membangun budaya literasi terutama pembelajaran yang dapat meningkatkan aktivitas peserta didik menggunakan bahan ajar dalam berkehidupan. Peserta didik belajar berbahasa atau bersastra untuk dunia nyata, bukan dunia sekolah. Di Yanni (1995:40) menyatakan bahwa pembelajaran berbasis literasi dilakukan dengan mengembangkan gagasan atau ide melalui pengembangan pertanyaan-pertanyaan pada waktu menulis, kemudian mengembangkannya melalui keterhubungan antar-ide dan kontroversi dari setiap ide.

Pembelajaran berbasis budaya literasi dalam dunia pendidikan memiliki keunggulan karena model literasi bukan hanya dimaksudkan agar siswa memiliki kapasitas mengerti makna konseptual dari wacana melainkan kemampuan berpartisipasi aktif secara penuh dalam menerapkan pemahaman sosial dan intelektual (White, 1985:56).

Pembelajaran berbasis budaya literasi akan mengondisikan peserta didik untuk menjadi seorang literat. Peningkatan kemampuan literasi dalam belajar sejalan dengan tujuan pendidikan, yaitu berkembangnya potensi peserta didik agar menjadi manusia yang beriman dan bertaqwa kepada Tuhan Yang Maha Esa, berahlak mulia, sehat, berilmu, cakap, kreatif, mandiri, dan menjadi warga negara yang demokratis serta bertanggung jawab (Depdiknas, 2003). Pemerolehan tujuan ini dapat dilakukan siswa jika mereka telah menjadi sosok literat. Para siswa memiliki bekal literasi dalam dirinya sehingga mampu melengkapi diri dengan kemampuan yang diharapkan.

Proses pengembangan kemampuan berbahasa dan bersastra dilaksanakan dengan cara mengembangkan kemampuan kognitif, analisis, sintesis, evaluasi, dan kreasi melalui suatu kajian langsung terhadap kondisi sosial dengan menggunakan kemampuan berpikir cermat dan kritis. Proses pemahaman peserta didik terhadap fenomena sosial dengan pengenalan secara langsung akan lebih memudahkan bagi pembelajar dalam mengembangkan kompetensinya. Peserta didik harus terbiasa dengan membaca berbagai informasi dan mengakses informasi dari media elektronis maupun media tertulis. Selain itu, ia perlu mengikuti perkembangan peradaban yang sedang terjadi secara faktual. Oleh karena itu, dalam mengembangkan kompetensi berbahasa dan bersastra berbasis literasi perlu didukung oleh ketersediaan fasilitas dalam membangun insan literat.

Aktivitas pendidik dalam kelas ketika melaksanakan pembelajaran bahasa Indonesia berbasis literasi lebih ringan, yaitu (1) mengarahkan aktivitas peserta didik; (2) memilih dan menyiapkan bahan pembelajaran; (3) memerika hasil kerja peserta didik; (4) mengarahkan sistem berkomunikasi keilmuan; (5) berkoordinasi dalam menyiapkan latar kelas kegiatan literasi.

\section{Standar Literasi}

Semua guru harus menyadari praktik terbaik dan data saat ini pada akuisisi bahasa dan kemahiran ilmiah. standar nasional dan negara yang dibuat untuk menetapkan tujuan untuk setiap tingkat kelas untuk tujuan mencapai optimum belajar siswa. Standar nasional dan orang-orang di kebanyakan negara, termasuk membaca seluruh teks yang berbeda, membaca kritis, dan membaca yang memungkinkan siswa untuk mewakili ide-ide, proses membaca kritis, selain berbagai strategi untuk digunakan dengan berbagai struktur teks.

Standar menekankan membaca untuk tujuan dan evaluasi kritis dari ide-ide. Standar untuk menulis sering termasuk mengembangkan rencana, pengorganisasian ide, menulis paragraf, memahami dan mengembangkan gaya, mengedit, dan menggunakan teknologi. Standar dalam bahasa lisan meminta siswa dapat berkomunikasi dengan jelas untuk berbagai khalayak dan bahwa siswa tahu bagaimana 
untuk mendengarkan secara aktif . Penggunaan teknologi untuk mencari dan mengolah informasi dan melaporkan temuan investigasi juga dibutuhkan dalam sains dan bahasa seni.

Bahkan dengan instruksi kelas yang baik dan intervensi perbaikan yang efektif, banyak siswa berjuang dengan buku teks dan satu ukuran cocok untuk semua pendekatan yang tersirat dalam penggunaannya. Jika mereka berjuang dengan membaca sains, siswa tidak dapat belajar banyak dari buku teks. Oleh karena itu, banyak guru hari ini menemukan bahwa mereka harus menggunakan metode dan bahan bacaan selain yang ditentukan oleh ilmu mereka. Mereka mungkin menulis ulang kurikulum, sering menghabiskan uang mereka sendiri pada buku perdagangan yang tepat untuk menemani.

Bagi guru untuk mengajarkan ilmu secara efektif di sekolah dasar, mereka INCOR - porate pengalaman berbasis penyelidikan aktif dalam pelajaran mereka. Mereka juga termasuk membaca, menulis, dan pengembangan kosakata.

\section{Standar Isi Pendidikan Sains Nasional}

1. Standar Isi A (Sains sebagai Kirim)

Sebagai hasil dari kegiatan di kelas K - 4, semua siswa harus mengembangkan:
a) kemampuan yang diperlukan untuk melakukan penyelidikan ilmiah
b) pemahaman tentang penyelidikan ilmiah

2. Standar Isi B (Ilmu Fisika)

Sebagai hasil dari kegiatan di kelas K - 4, semua siswa harus mengembangkan pemahaman tentang :
a) Sifat benda dan bahan
b) posisi dan gerak benda
c) cahaya, panas, listrik, dan magnet

3. Standar Isi C (Life Science)

Sebagai hasil dari kegiatan di kelas K - 4, semua siswa harus mengembangkan pemahaman tentang :
a) karakteristik organisme
b) kehidupan siklus organisme
c) organisme dan lingkungan

4. Standar Isi D (Bumi dan Space Science) Sebagai hasil dari kegiatan di kelas K-4, semua siswa harus mengembangkan pemahaman tentang:
a) Sifat dari bahan tanah
b) benda di langit
c) perubahan bumi dan langit

5. Standar Isi E (Sains dan Teknologi)

Sebagai hasil dari kegiatan di kelas K-4, semua siswa harus mengembangkan:

a) kemampuan desain teknologi

b) pemahaman tentang ilmu pengetahuan dan teknologi

c) kemampuan untuk membedakan antara benda-benda alam dan benda-benda yang dibuat oleh manusia

6. Standar Isi F (Science dalam Personal dan Sosial Perspektif)

Sebagai hasil dari kegiatan di kelas K-4, semua siswa harus mengembangkan pemahaman tentang:
a) kesehatan pribadi
b) karakteristik dan perubahan populasi
c) jenis sumber
d) perubahan lingkungan
e) ilmu pengetahuan dan teknologi dalam tantangan lokal

7. Standar Isi G (Sejarah dan Alam Ilmu)

Sebagai hasil dari kegiatan di kelas K-4, semua siswa harus mengembangkan pemahaman tentang:
a) ilmu sebagai usaha manusia
b) hakikat ilmu
c) sejarah ilmu pengetahuan

Catatan. Dari Dewan Riset Nasional (1996).

Standar untuk Bahasa Inggris Seni dari NCTE dan IRA

Visi membimbing standar ini adalah bahwa semua siswa harus memiliki kesempatan dan sumber daya untuk mengembangkan keterampilan bahasa yang mereka butuhkan untuk mengejar tujuan hidup dan untuk berpartisipasi sepenuhnya sebagai, anggota produktif informasi masyarakat. Standar ini mengasumsikan bahwa pertumbuhan keaksaraan dimulai sebelum anak masuk sekolah karena mereka mengalami dan bereksperimen dengan keaksaraan kegiatanmembaca dan menulis, dan bergaul kata yang diucapkan dengan representasi grafis mereka. 
Menyadari fakta ini, standar ini mendorong pengembangan kurikulum dan pengajaran yang menggunakan produktif kemampuan keaksaraan yang muncul bahwa anak-anak membawa ke sekolah.

Selain itu, Dewan Nasional Guru Bahasa Inggris dan Asosiasi Reading International (1996) memaparkan bahwa standar memberikan banyak ruang untuk inovasi dan kreativitas penting untuk mengajar dan belajar. Mereka tidak resep untuk kurikulum atau instruksi tertentu. Meskipun kami menyajikan standarstandar ini sebagai daftar, kami ingin menekankan bahwa mereka tidak berbeda dan terpisah mereka, pada kenyataannya, saling terkait dan harus dipertimbangkan secara keseluruhan, yaitu :

1. Siswa membaca berbagai cetak dan teks non cetak untuk membangun pemahaman teks, dari diri mereka sendiri, dan budaya dari Amerika Serikat dan dunia untuk memperoleh informasi baru; untuk merespon kebutuhan dan tuntutan masyarakat dan tempat kerja; dan untuk pemenuhan pribadi. Di antara teks-teks ini fiksi dan nonfiksi, klasik dan karyakarya kontemporer.

2. Siswa membaca berbagai literatur dari berbagai periode dalam banyak genre untuk membangun pemahaman dari banyak dimensi (misalnya, filsafat, etika, estetika) dari pengalaman manusia.

3. Siswa menerapkan berbagai strategi untuk memahami, menafsirkan, mengevaluasi, dan menghargai teks. Mereka menarik pengalaman mereka sebelumnya, interaksi mereka dengan pembaca dan penulis lain, pengetahuan mereka tentang arti kata dan teks-teks lain, strategi identifikasi kata-kata mereka, dan pemahaman mereka tentang fitur tekstual (misalnya suara-surat menyurat, struktur kalimat, konteks, grafis ).

4. Siswa menyesuaikan penggunaan lisan, tertulis, dan bahasa visual (misalnya, konvensi, gaya, kosakata) untuk berkomunikasi secara efektif dengan berbagai khalayak dan untuk tujuan yang berbeda.

5. Siswa menggunakan berbagai strategi seperti mereka menulis dan menggunakan elemen proses penulisan yang berbeda tepat untuk berkomunikasi dengan audiens yang berbeda untuk berbagai tujuan.

6. Siswa menerapkan pengetahuan tentang struktur bahasa, konvensi bahasa (misalnya, ejaan dan tanda baca), teknik media, bahasa kiasan, dan genre untuk membuat, kritik, dan membahas cetak dan teks nonprint.

7. Siswa melakukan penelitian tentang isuisu dan kepentingan dengan menghasilkan ide-ide dan pertanyaan, dan oleh masalah berpose. Mereka mengumpulkan, mengevaluasi, dan mensintesis data dari berbagai sumber (misalnya, cetak dan teks nonprint, artefak, orang) untuk berkomunikasi penemuan mereka dengan cara yang sesuai dengan tujuan dan audiens mereka.

8. Siswa menggunakan berbagai sumber daya teknologi dan informasi (misalnya, perpustakaan, database, jaringan komputer, video) untuk mengumpulkan dan mensintesis informasi dan untuk membuat dan mengkomunikasikan pengetahuan.

9. Siswa mengembangkan pemahaman tentang dan menghormati keragaman dalam penggunaan bahasa, pola, dan dialek antar budaya, kelompok etnis, wilayah geografis, dan peran sosial.

10. Mahasiswa yang bahasa pertamanya bukan bahasa Inggris menggunakan bahasa pertama mereka untuk mengembangkan kompetensi dalam seni bahasa Inggris dan untuk mengembangkan pemahaman tentang konten di kurikulum.

11. Siswa berpartisipasi sebagai anggota berpengetahuan, reflektif, kreatif, dan kritis dari berbagai komunitas literasi.

12. Siswa menggunakan lisan, tertulis, dan bahasa visual untuk mencapai tujuan 
mereka sendiri (misalnya, untuk belajar, kenikmatan, persuasi, dan pertukaran informasi).

\section{Standar Literasi Informasi bagi Pendidikan Sekolah}

Rumusan tentang standar kompetensi literasi informasi untuk pendidikan tinggi dilakukan oleh Komite Standar ACRL dan disetujui oleh Dewan Direksi Association of College and Research Libraries (ACRL) pada 18 Januari 2000. ACRL telah mengeluarkan lima standar literasi informasi dalam dunia perguruan tinggi dan kelima standar tersebut memiliki 22 indikator. Standar literasi ini berisi daftar sejumlah kemampuan yang digunakan dalam menentukan kemampuan seseorang dalam memahami informasi. Dalam standar ini terdapat cara bagaimana mahasiswa dapat berinteraksi dengan informasi. Standar ini juga digunakan oleh fakultas, pustakawan, dan staf lainnya dalam mengembangkan metode untuk mengukur pembelajaran mahasiswa sesuai dengan misi institusi tersebut. Standar kompetensi literasi informasi dari ACRL (2000, 8) tersebut yaitu:

1. Siswa yang literat informasi mampu menentukan jenis dan sifat informasi yang dibutuhkan.

a. Siswa mendefinisikan dan menyampaikan kebutuhan informasinya.

b. Siswa mengidentifikasi berbagai jenis dan bentuk sumber informasi yang potensial.

c. Siswa mempertimbangkan biaya dan keuntungan yang diperoleh dari informasi yang dibutuhkan.

d. Siswa mengevaluasi kembali sifat dan batasan informasi yang dibutuhkan.

2. Siswa yang literat informasi mengakses kebutuhan informasi secara efektif dan efisien.

a. Siswa memilih metode penelitian dan sistem temu kembali informasi yang paling tepat untuk mengakses informasi yang dibutuhkan.

b. Siswa membangun dan menerapkan strategi penelusuran yang efektif. c. Siswa melakukan sistem temu kembali secara online atau pribadi dengan menggunakan berbagai metode.

e. Siswa memperbaiki strategi penelusuran jika diperlukan

f. Siswa mengutip, mencatat dan mengolah informasi dan sumbersumbernya.

3. Siswa yang literat mengevaluasi informasi dan sumber-sumber secara kritis dan menjadikan informasi yang dipilih sebagai dasar pengetahuan.

a. Meringkas ide utama yang dikutip dari informasi yang dikumpulkan.

b. Siswa menentukan dan menerapkan kriteria awal untuk mengevaluasi informasi dan sumber-sumbernya.

c. Siswa mampu mensintesis ide utama untuk membangun konsep baru.

d. Siswa membandingkan pengetahuan baru dengan pengetahuan lama untuk menentukan nilah tambah, kontradiksi, atau karakteristik informasi unik lainnya dari informasi.

e. Mahasiswa menentukan apakah pengetahuan baru memberi dampak terhadap sistem nilai individu dan mengambil langkah-langkah untuk menyatukan perbedaan.

f. Siswa menentukan bila query perlu direvisi.

4. Siswa yang literat menggunakan dan mengkomunikasikan informasi dengan efektif dan efisien.

a. Siswa menerapkan informasi baru dan yang lama untuk merencanakan dan menciptakan hasil.

b. Siswa merevisi proses pengembangan untuk hasil.

c. Siswa mengkomunikasikan hasil secara efektif kepada orang lain.

5. Siswa yang literat informasi memahami isu ekonomi, hukum dan sosial sekitar penggunaan dan pengaksesan informasi secara etis dan hukum

a. Siswa memahami isu-isu ekonomi, hukum dan aspek sosial mengenai informasi dan teknologi informasi. 
b. Siswa mematuhi hukum, peraturan, kebijakan intitusi, dan etika yang berhubungan dengan pengaksesan dan penggunaan sumber informasi

c. Siswa mengetahui penggunaan sumber-sumber informasi dalam mengkomunikasikan informasi.

Guru perlu untuk mengajar dan membimbing pengalaman keaksaraan bahasa tertentu setiap hari. Banyak guru menggunakan dipandu kelompok membaca, lingkaran sastra, 'lokakarya, dan metode lain yang membantu mereka bervariasi instruksi dan menciptakan konteks untuk siswa penulis aktif, pembelajaran konstruktif. Seperti yang dinyatakan sebelumnya, ada dapat dan harus jelas expecsultasi untuk akumulasi untuk mata pelajaran lainnya. Siswa harus bertanggung jawab untuk keterampilan lan-gauge kunci yang diperlukan untuk belajar ilmu pengetahuan.

Ketika siswa menyadari bahwa apa yang mereka pelajari dalam seni bahasa dimaksudkan untuk digunakan baik di dalam dan di luar sekolah, mereka tidak mengeluh, "Mengapa kita harus mengeja dengan benar atau menggunakan paragraf di sci-ence?" Penggunaan keterampilan yang telah diajarkan dan diperkuat baik selama pelajaran seni bahasa (seperti penggunaan huruf kapital dan periode di kelas dua) dapat diharapkan. siswa sekolah dasar dapat bertanggung jawab untuk ejaan yang benar dari kata-kata khusus unit kosa kata dalam daftar kata ditampilkan secara jelas, atau katakata ejaan umum bahwa mereka harus menguasai selama pelajaran ejaan. guru perlu menjadi hakim. Namun, penting untuk diingat bahwa harus fokus, pertama, pada konsep dan, kedua, dalam perjalanan mereka Repre-sented ketika ilmu pengetahuan terintegrasi dengan menulis.

Siswa harus diajarkan strategi khusus untuk mendapatkan hasil maksimal dari teks infor-mational. Mereka harus diajarkan bagaimana untuk terlibat dalam proses penyelidikan dan bagaimana menggunakan berbagai jenis teks informasi yang mereka miliki, mulai dari ensiklopedi ke Internet, majalah dan buku perdagangan.
Kami tidak ingin mengabaikan pentingnya memiliki perpustakaan kelas penuh dari semua jenis bahan bacaan. Harus ada buku di berbagai tingkatan membaca pada berbagai mata pelajaran ilmu pengetahuan. majalah ilmiah dan newsletter dipajang menarik siswa dengan isu-isu kontemporer dan eksplorasi. Ada juga harus ada ruang bagi siswa untuk membawa buku dan artefak dari rumah, juga untuk menjaga koleksi terbuka.

Keaksaraan bahasa dan literasi sains dapat dengan mudah dihubungkan untuk memungkinkan guru untuk lebih mencapai tujuan mereka dan untuk mematuhi standar dalam kerangka waktu yang mereka miliki. Dengan pendekatan terpadu tersebut, guru memiliki tak berujung opportu-nities untuk mengembangkan bahasa dan membaca strategi siswa.

Penyelidikan berbasis pengalaman ilmu memberikan konteks di mana siswa belajar untuk berpikir kritis dan mengembangkan pemahaman dari kegiatan beton dan bahan cetak. Puncak alami dari jenis belajar adalah bahwa anak-anak belajar untuk berbagi penemuan mereka dalam bentuk tertulis dan lisan.

\section{SIMPULAN}

Pembelajaran bahasa Indonesia di sekolah-sekolah diarahkan pada upaya membangun budaya literasi. Oleh karena itu, para pendidik seharusnya memahami konsep literasi secara mantap agar menggeser kebiasaan dari mengajar menjadi membelajarkan siswa berbahasa atau bersastra.

Berbagai upaya perlu dilakukan guru dalam meningkatkan kualitas pembelajaran bahasa Indonesia dengan memerhatikan esensi dari "belajar" berbahasa atau bersastra Indonesia. Siswa belajar bahasa Indonesia itu meliputi keseluruhan kompetensi berbahasa, yaitu mendengarkan, berbicara, membaca, dan menulis bukan hanya mendengarkan tentang bahasa atau tentang sastra.

Prosiding ini membahas tentang kajian literasi, membangun budaya literasi, serta standar literasi. Penulis masih mengharapkan 
kritik dan masukan dari para pembaca agar makalah ini lebih sempurna.

\section{DAFTAR PUSTAKA}

Jurnal Novi Resmini. Orasi Dan Literasi Dalam Pengajaran Bahasa. Universitas pendidikan indonesia

Jurnal Heny Subandiyah. Pembelajaran Literasi Dalam Mata Pelajaran Bahasa Indonesia. Universitas negeri Surabaya
Mckee. Judi dan donna olge. 2005. Integrating Instruction Literaty An Sciense. The gulforld press. New york

Http://www.mannlib.cornell.edu/ pmd8/literacy /.html. [4 februari 2001] 